УДК 347.7

DOI https://doi.org/10.32849/2663-5313/2021.4.01

\title{
Вікторія Борівсъка,
} студентка IV курсу юридичного факультету

Донецького національного університету імені Василя Стуса

\section{Тетяна Міхайліна,}

докт. юрид. наук, професор,

професор кафедри теорії та історії держави і права та адміністративного права

Донецького національного університету імені Василя Стуса

\section{ПРАВОВИЙ РЕЖИМ ВЕБСАЙТУ ТА ЙОГО СКЛАДНИКІВ ЯК ОБ'ЄКТІВ ІНТЕЛЕКТУАЛЬНОЇ ВЛАСНОСТІ}

Метою статті є аналіз та уточнення правового режиму вебсайту і його складових частин як об'єктів інтелектуальної власності.

В результаті дослідження визначено, що вебсайт виступає комплексним за структурою, окремим і самостійним об'єктом права інтелектуальної власності у сфері авторського права, оскільки під час створення потребує використання творчих здібностей людини та не має чітко визначеної структури, а саме може складатися з різних об'єктів права інтелектуальної власності, в різних комбіначіях та з особливим їх впорядкуванням, що, як наслідок, породжує оригінальність та унікальність кожного вебсайту. Зроблено висновок, що не можна ототожнювати комп'ютерну програму та вебсайт. Крім того, не можна вважати вебсайт лише сукупністю графічних, візуальних, літературних, та інших творів, оскільки це визначення не охоплює всю його сутність. Також варто відзначити, що саме невизначеність чіткої кількості структурних елементів у цьому об'єкті відіграє значну роль у творчому процесі створення останнъого.

Аргументовано необхідність розширення законодавчого поняття «вебсайт», а саме вебсайт - ие комплексний об'єкт авторського права, що являє собою сукупність апаратного й програмного забезпечення, доменного імені, вебдизайну, інформаційного наповнення (контенту) та інших об'єктів авторського права і (або) суміжних прав тощо, які пов'язані між собою в різних комбінаціях та з особливим їх впорядкуванням. При ивому обумовленим є доповнення переліку об'єктів авторського права у ст. 8 Закону України «Про авторське право та суміжні права» та переліку об'єктів права інтелектуальної власності у ст. 420 Цивільного кодексу України окремим пунктом «вебсайт».

Виявлено, що вебсайт є комплексним об'єктом права інтелектуальної власності, який складається з інших його об'єктів. Водночас відповідні елементи перебувають у спечіальному індивідуальному порядку щодо кожного вебсайту та своєю сукупністю визначаютьь його оригінальність. Зазначено, що до структури вебсайту належать такі ключові елементи, як контент, апаратні та програмні засоби, вебсторінка, доменне ім'я та вебдизайн. Особливістю иих складових частин є те, що вони є різними за своєю правовою природою об'єктами права інтелектуальної власності.

Ключові слова: вебсайт, інтернет-сайт, правовий режим, об’єкт інтелектуальної власності, авторське право, суміжні права, охорона прав, інформаційне суспільство.

Постановка проблеми. Всесвітня інформаційна система загального доступу, або Інтернет, з моменту свого створення стала невід'ємною частиною сучасного світу. При цьому нині жодна людина не уявляє Інтернет без вебсайту, оскільки він є ключовим елементом Інтернету, за допомогою якого користувачі мають змогу отримувати доступ до інформації. Оскільки з кожним роком кількість вебсайтів та масив поширеної інформації збільшується, то закономірно виникає потреба створення механізму правового регулювання відносин, пов’язаних із вебсайтом та опублікованою на ньому інформацією.

Водночас науковці у своїх дослідженнях вказують на складну природу вебсайту та здебільшого відносять його до об'єктів права інтелектуальної власності. Однак у зв'язку з новизною такого явища, як вебсайт, у науковій доктрині ще не випрацьовувалось чітке поняття вебсайту, а також його місце в системі об'єктів права інтелектуальної власності, як і форми та способи ефективного захисту прав інтелектуальної власності в мережі Інтернет. 
До поняття вебсайту, його структури та характеристик звертались такі науковці, як В.Б. Наумов, М.В. Гура, О.С. Фелечко, К.О. Зеров, С.А. Булат, Н.В. Філик, В.Ю. Молодід, Ю.Е. Атаманова, Н.І. Майданик, А.В. Кирилюк, Ю.В. Маслюк, Л.Л. Тарасенко, А.О. Гордеюк, А.А. Клименко, В.О. Каландей. Таким чином, грунтовне наукове дослідження вебсайту, зокрема правового режиму його інформаційного наповнення, має стати поштовхом для продовження законодавцем процесу правового впорядкування аналізованих суспільних відносин та розроблення способів якісного захисту прав інтелектуальної власності в мережі Інтернет.

Метою статті $\epsilon$ аналіз та уточнення правового режиму вебсайту та його складових частин як об'єктів інтелектуальної власності.

Виклад основного матеріалу. Вебсайт (інтернет-сайт) є одиницею віртуального простору, за допомогою якої можна зберігати різноманітну інформацію, маючи доступ для ознайомлення та обміну з будь-якої точки планети.

Безпосередньо вебсайт виник не так давно, а саме його було створено у 1990 р. фізиком Тімом Бернерс-Лі [1]; одразу з моменту його створення серед науковців 3 різних країн почали виникати дискусії щодо правової природи цього предмета дослідження. Серед українських дослідників це питання почало викликати значний інтерес уже на початку XXI століття. Так, В.Б. Наумов визначив вебсайт як системно впорядковану сукупність вебсторінок, що об'єднані гіперпосиланнями, при цьому кожна вебсторінка сайту має свою унікальну адресу в мережі Інтернет і є своєрідною програмою, написаною за допомогою команд мови HTML, що покликана керувати відображенням вебсторінки під час доступу до неї користувачів [2, с. 201]. Дещо подібним є визначення М.В. Гури, який розуміє вебсайт як логічно завершений елемент мережі Інтернет, який створений на основі технології гіперпосилань, розташований на сервері (host), має унікальну адресу (url), за якою до нього може отримати доступ будьякий користувач мережі Інтернет, а у своїй основі містить інтернет-сторінки, які мають графічний вигляд і можуть переглядатися за допомогою спеціальних програм (браузерів) [3, с. 35].

Водночас на законодавчому рівні вперше було визначено поняття «вебсайт» у спільному Наказі Державного комітету інформаційної політики, телебачення та радіомовлення України та Державного комітету зв'язку та інформатизації України «Про затвердження Порядку інформаційного наповнення та технічного забезпечення Єдиного вебпорталу органів виконавчої влади та Порядку функціонування вебсайтів органів виконавчої влади» від 25 листопада 2002 р. № 327/225, де зазначається, що вебсайт - це сукупність програмних та апаратних засобів з унікальною адресою у мережі Інтернет разом з інформаційними ресурсами, що перебувають у розпорядженні певного суб'єкта й забезпечують доступ юридичних та фізичних осіб до цих інформаційних ресурсів, а також інші інформаційні послуги через мережу Інтернет [4]. У цьому нормативно-правовому акті було надано визначення вебсайту як певного поєднання технічної та інформаційної складових частин.

При цьому на рівні закону відповідне поняття законодавці затвердили лише 26 квітня 2017 р. у новій редакції Закону України «Про авторське право і суміжні права» (Закон № 3792-XII), де зазначається, що вебсайт - це сукупність даних, електронної (цифрової) інформації, інших об'єктів авторського права і (або) суміжних прав, пов'язаних між собою і структурованих у межах адреси вебсайту та (або) облікового запису власника цього вебсайту, доступ до яких здійснюється через адресу мережі Інтернет, що може складатися 3 доменного імені, записів про каталоги або виклики і (або) числової адреси за інтернет-протоколом [5]. 3 аналізу стає зрозумілим, що законодавець у новій редакції Закону розширив поняття вебсайту, зазначивши його як складний структурний об'єкт, що містить невизначену кількість елементів (причому не простих за своєю природою елементів, а окремих об'єктів права інтелектуальної власності), поєднаних між собою в особливому порядку. Також слід зазначити, що досі це визначення залишилося незмінним.

Проте, проаналізувавши наведені поняття науковців та законодавця, розуміємо, що в них відсутня пряма вказівка на приналежність вебсайту до об'єктів права інтелектуальної власності, як і в інших НПА, а саме у ст. 8 вищезазначеного Закону та ст. 420 ЦКУ вебсайт до переліку об'єктів авторського права та переліку об'єктів права інтелектуальної власності не включений. При цьому до переліку об'єктів авторського права у ст. 8 Закону № 3792-XII включено «інші твори», тому виникає спір між науковцями щодо того, чи є вебсайт окремим об'єктом права інтелектуальної власності або він $\epsilon$ просто носієм інформації, яка належить до об'єктів права інтелектуальної власності.

Оскільки вебсайт складається 3 різних вебсторінок, які перебувають у певному 
порядку та $\epsilon$ своєрідними програмами, індивідуального доменного імені, спільного дизайну й містить певну інформацію, то можна зробити висновок, що вебсайт утворює своєрідну нову та оригінальну «композицію» 3 поєднанням у собі невичерпної кількості елементів. 3 огляду на це стає чітко зрозумілою наявність творчого характеру. Аргументом до цього висновку слугує метод реалізації мети створення вебсайту, яка полягає в тому, що складові частини вебсайту спеціально підбираються та розташовуються у певній комбінації, з певним задумом, що є ознакою творчого характеру.

Більшість фахівців 3 інтелектуальної власності згодна 3 тим, що вебсайт - це об'єкт права інтелектуальної власності. Однак питання, до якого інституту цього права зазначений об'єкт належить, залишається відкритим. Як зазначає О.С. Фелечко у своєму дослідженні, «різні науковці відносять вебсайт до різновиду комп'ютерної програми; сукупності графічних, візуальних, літературних та інших творів, кожен з яких є самостійним об'єктом авторського права; складеного твору; бази даних; окремого файлу, який зчитує комп'ютерна програма» [6]. При цьому найпоширенішим варіантом $є$ віднесення вебсайту саме до комп'ютерної програми.

Так, Держдепартамент інтелектуальної власності у Листі від 25 листопада 2004 р. № 16-14/5105 зазначив, що програмне забезпечення для вебсайту, програмні засоби вебсайту є комп'ютерними програмами, оскільки являють собою набір інструкцій у вигляді слів, цифр, кодів, схем, символів чи у будьякому іншому вигляді, виражені у формі, придатній для зчитування комп'ютером, які приводять його у дію для досягнення певної мети або результату, а також охоплюються поняттям комп'ютерної програми, визначеним у ст. 1 Закону України «Про авторське право і суміжні права». Проте Міністерство юстиції України у Листі від 18 грудня 2006 р. № 19-5-537 зазначило, що «на законодавчому рівні чітко не встановлено, що вебсайти належать до комп'ютерних програм», а також порекомендувало за більш детальними роз'ясненнями звертатися до Держдепартаменту інтелектуальної власності як до державного органу, уповноваженого давати відповіді на такі запитання.

Водночас вихідним продуктом комп'ютерної програми є виконуваний код, що створюється за допомогою мов програмування. Розмітка гіперпосилань, хоч і $€$ набором інструкцій, але не є мовою програмування; цей механізм застосовується лише задля відображення інформації [7, с. 49], тому комп'ютерну програму та вебсайт не можна ототожнювати.

Ще однією досить популярною позицією $€$ визначення вебсайту як сукупності кількох об'єктів права інтелектуальної власності. Цей висновок науковці роблять на основі так званої зовнішньої сторони вебсайту, а саме змістовного та інформаційного його наповнення. Таким чином, не можна вважати вебсайт лише сукупністю графічних, візуальних, літературних та інших творів, оскільки це визначення не охоплює всю його сутність.

Так, можна погодитися 3 позицією Є.А. Булата про те, що правова природа вебсайту має комплексний характер з огляду на його технічну складову частину та графічне й інформаційне оформлення [8, с. 16]. Крім того, на думку Н.В. Філика та В.Ю. Молодіда, вебсайт через свою оригінальність та необхідність застосування розумових i творчих навичок під час його створення приречений стати об'єктом права інтелектуальної власності, а саме авторського права. Причому у зв'язку з доступністю інформації щодо навчання комп'ютерному програмуванню та вебдизайну допускається можливість створення цього об'єкта будь-якою особою, але переважно інтернет-сайт створюється на замовлення як службовий твір чи за договором створення об'єкта авторського права [9, с. 306]. 3 цією позицією у своїх дослідженнях погоджуються такі науковці, як Н.І. Майданик, Л.Л. Тарасенко, А.О. Гордеюк $[10 ; 11 ; 12]$. Таким чином, вебсайт виступає комплексним за структурою, окремим і самостійним об'єктом права інтелектуальної власності у сфері авторського права, оскільки під час створення потребує використання творчих здібностей людини та не має чітко визначеної структури, а саме може складатися 3 різних об’єктів права інтелектуальної власності, в різних комбінаціях та 3 особливим їх впорядкуванням, що, як наслідок, породжує оригінальність та унікальність кожного вебсайту, тобто, поєднуючи різнорідні за своїм характером об'єкти, вебсайт має ознаки, що не є сукупністю ознак його складових частин. При цьому додатковими ознаками приналежності до авторського права для вебсайту є те, що останній належить до творів мистецтва, науки, літератури, має об'єктивну форму вираження через своє програмне забезпечення й поширення в мережі Інтернет, а також є відтворюваним.

3 огляду на вищезазначене виникає необхідність розширення законодавчого поняття вебсайту, а саме вебсайт - це комплексний об'єкт авторського права, що являє собою сукупність апаратного й програмного забез- 
печення, доменного імені, вебдизайну, інформаційного наповнення (контенту) та інших об'єктів авторського права і (або) суміжних прав, які пов'язані між собою в різних комбінаціях та $з$ особливим їх впорядкуванням. При цьому обумовленим є доповнення переліку об'єктів авторського права у ст. 8 Закону України «Про авторське право та суміжні права» та переліку об'єктів права інтелектуальної власності у ст. 420 Цивільного кодексу України окремим пунктом «вебсайт».

Отже, вебсайт є комплексним об'єктом права інтелектуальної власності, який складається 3 інших його об'єктів. Водночас відповідні елементи знаходяться у спеціальному індивідуальному порядку щодо кожного вебсайту та своєю сукупністю визначають його оригінальність. При цьому «сукупність інших об'єктів права інтелектуальної власності як елементів вебсайту» є досить широким та «розмитим» у своєму трактуванні визначенням, тому існують різні позиції науковців щодо питання переліку необхідної сукупності об'єктів права інтелектуальної власності для визначення вебсайту як окремого твору. Так, К.О. Зеров зазначає, що існують як обов'язкові елементи (контент вебсайту, структурний розв'язок), так і факультативні (дизайн, програмне забезпечення), визначаючи доменне ім'я як самостійний об'єкт, призначений для індивідуалізації учасників цивільного обігу в мережі Інтернет, пов'язаний із товарними знаками (торговельними марками), а не з інститутом авторського права [13, с. 29-30]. Проте H.I. Майданик зазначає, що мінімальний набір елементів вебсайту передбачає дизайн, структурний розв'язок, програмне забезпечення, контент, доменне ім'я [10, с. 74].

Ю.С. Атаманова вважає, що для досягнення формальної та змістовної єдності вебсайтом необхідна наявність таких його складових частин, як програмні та апаратні засоби (серверні програмні засоби; програмні засоби сайту); адреса в мережі Інтернет або доменне ім'я; інформаційне наповнення, яке охоплює текстову, графічну та аудіовізуальну інформацію [14, с. 8]. При цьому можна погодитися з позиціями H.I. Майданика та Ю.С. Атаманової, оскільки для нормальної «життєдіяльності» вебсайту потрібне власне унікальне ім'я (домен), він функціонує за допомогою засобів програмування, містить певну графіку й візуалізацію інформації, яка має бути придатна для використання користувачами Інтернету. Також подібною є позиція А.В. Кирилюк, яка визначає чотири складові частини вебсайту, такі як апаратна складова частина, програмні засоби, вебсторінка сайту, що має унікальну адресу, та контент [15, с. 14].

Враховуючи вищенаведені необхідні складові частини вебсайту, можемо дійти висновку, що саме поєднання апаратного та програмного забезпечення, доменного імені, вебдизайну й контенту становить вебсайт. Водночас у цьому абзаці наведені лише необхідні елементи, а їхня наявність не виключає інших необов'язкових складових частин (облікові записи користувачів вебсайту, велика кількість вебсторінок) Також варто відзначити, що саме невизначеність чіткої кількості структурних елементів у цьому об'єкті відіграє значну роль у творчому процесі створення останнього. Крім того, слід пам'ятати, що структурні елементи вебсайту окремо мають також непросту характеристику, а саме всі вони, як і вебсайт, підлягають охороні як об'єкти права інтелектуальної власності.

\section{Висновки}

В результаті дослідження визначено, що вебсайт виступає комплексним за структурою, окремим і самостійним об'єктом права інтелектуальної власності у сфері авторського права, оскільки під час створення потребує використання творчих здібностей людини та не має чітко визначеної структури, а саме може складатися з різних об'єктів права інтелектуальної власності в різних комбінаціях та з особливим їх впорядкуванням, що, як наслідок, породжує оригінальність та унікальність кожного вебсайту.

На підставі вищезазначеного аргументовано необхідність розширення законодавчого поняття вебсайту, а саме вебсайт - це комплексний об'єкт авторського права, що являє собою сукупність апаратного й програмного забезпечення, доменного імені, вебдизайну, інформаційного наповнення (контенту) та інших об'єктів авторського права i (або) суміжних прав, які пов’язані між собою в різних комбінаціях та з особливим їх впорядкуванням. При цьому обумовленим $є$ доповнення переліку об'єктів авторського права у ст. 8 Закону України «Про авторське право та суміжні права» та переліку об'єктів права інтелектуальної власності у ст. 420 Цивільного кодексу України окремим пунктом «вебсайт».

Водночас виявлено, що до структури вебсайту належать такі ключові елементи, як контент, апаратні та програмні засоби, вебсторінка, доменне ім'я та вебдизайн. Особливістю цих складових частин є те, що вони є різними за своєю правовою природою об'єктами права інтелектуальної власності. 


\section{Список використаних джерел:}

1. Історія створення першого в світі сайту. Web Building. URL: https://webbuilding.com.ua/ $\mathrm{ukr} /$ articles/istoriya-stvorennya-pershogo-saytu (дата звернення: 08.06.2019).

2. Наумов В.Б. Право и Интернет: очерки теории и практики. Москва : Книжный дом «Университет», 2002. 201 с.

3. Гура М.В. Право інтелектуальної власності в Інтернеті. Правова охорона інтернет-сайту в Україні. Украӥнський юрист. 2004. № 10 (22). С. 34-35.

4. Про затвердження Порядку інформаційного наповнення та технічного забезпечення Сдиного вебпорталу органів виконавчої влади та Порядку функціонування вебсайтів органів виконавчої влади : Наказ Державного комітету інформаційної політики, телебачення та радіомовлення України та Державного комітету зв'язку та інформатизації України від 25 листопада 2002 р. № 327/225. Офiиійний вісник України. 2003. № 2. Ст. 154.

5. Про авторське право і суміжні права : Закон України від 23 грудня 1993 р. № 3792-XII. Вiдомості Верховної Ради України. 1994. № 13. Ст. 64 (із змінами).

6. Фелечко О.С. Вебсайт: від поняття до створення та функціонування. IT-право: проблеми перспективи розвитку в Украӥні (друга міжнародна щорічна конферениія). URL: http://aphd.ua/ publication-363 (дата звернення: 17.11.2019).

7. Зеров К.О. Особливості захисту прав на твори, розміщені в мережі Інтернет : монографія. Київ : Інтерсервіс, 2018. 220 с.

8. Булат Є.А. До питання правової охорони вебсайту. Науковий вісник Міжнародного гума- нітарного університету. Серія: Юриспруденція. 2015. № 13 (2). С. 16-17.

9. Філик Н.В., Молодід В.Ю. Інтернет-сайт як особливий об'єкт авторсько-правового захисту. Держава $і$ право. Серія: Юридичні $i$ політичні науки. 2011. № 54. С. 305-310.

10. Майданик H.I. Web-сайт в мережі Інтернет як особливий об'єкт авторського права. Юридична Україна: Правовий часопис. 2008. № 12. C. $73-80$.

11. Тарасенко Л.Л. Інтернет-сайт як об'єкт права інтелектуальної власності. Юридичний холдинг. URL: http://yurholding.com/news/118nternet-sayt-yak-obyekt-prava-ntelektualnoyivlasnost.html (дата звернення: 13.02.2020).

12. Гордеюк А.О. Проблема вдосконалення правового регулювання вебсайтів і доменних імен в умовах інформатизації суспільства. Гуманітарний часопис. 2019. № 2. С. 73-83.

13. Зеров К.О. Вебсайт як непоіменований об'єкт авторського права. Науковий вісник міжнародного гуманітарного університету. 2013. № 6 (3). C. 28-30.

14. Атаманова Ю.Е. Захист прав інтелектуальної власності у мережі Інтернет: світовий досвід та вітчизняні перспективи. Право та інноваиіï. 2014. № 3. С. 7-14.

15. Кирилюк А.В. Сайт та його наповнення (контент) як об'єкт правовідносин. Дискусї̈ щодо методики викладання та самонавчання: від римсъкого приватного права до сучасності; від курсової роботи до дисертачї. Забезпечення оригінальності творів: невирішені питання : матеріали відкритого міжкафедрального семінару (Одеса, 23 травня 2016 р.). Одеса : Фенікс, 2016. С. 13-17.

Victoriia Borivska, Tetiana Mikhailina. Legal regime of the website and its components as objects of intellectual property

The purpose of the scientific article is to analyze and clarify the legal regime of the website and its components as objects of intellectual property.

As a result of the study, it is determined that the Website is a complex structure, a separate and independent object of intellectual property rights in the field of copyright, since it requires the use of creative abilities of a person and does not have a clearly defined structure. So, it can consist of various objects of intellectual property rights, in various combinations and with a special ordering, which, as a result, generates the originality and uniqueness of each website. It is concluded that it is impossible to identify a computer program and a website. In addition, a website cannot be considered only a collection of graphic, visual, literary, and other works, since this definition does not cover its entire essence. It is also worth noting that it is the uncertainty of a clear number of structural elements in a given object plays a significant role in the creative process of creating the latter.

The necessity of expanding the legislative concept of a "website" is argued, namely: a website is a complex object of copyright, which is a set of hardware and software, domain name, web design, information content and other objects of copyright and (or) related rights, etc., which are related in various combinations and with their special ordering. At the same time, the additions of the list of objects of copyright in art. 8 of the law of Ukraine "On copyright and related rights" and the list of objects of intellectual property rights in art. 420 of the Civil Code of Ukraine as a separate item "website" are proposed.

It is revealed that the website is a complex object of intellectual property rights, which consists of its other objects. At the same time, the relevant elements are located in a special individual order for each website and their totality determines its originality. It is noted that the structure of the website includes such key elements as: content, hardware and software, web page, domain name and web design. The peculiarity of these components is that they are objects of intellectual property rights that differ in their legal nature.

Key words: website, Internet site, legal regime, intellectual property object, copyright, related rights, rights protection, information society. 